\title{
KARAKTERISTIK KITOSAN DARI LIMBAH CANGKANG UDANG WINDU (Panaeus monodon)
}

\author{
Eko Cahyono \\ Program Studi Teknologi Pengolahan Hasil Laut, Jurusan Perikanan dan Kabaharian Politeknik Negeri Nusa \\ Utara. Jalan Kesehatan No 1 Tahuna, Kepulauan Sangihe, Sulawesi Utara \\ *Korespondensi: ekocahyono878@gmail.com
}

\begin{abstract}
Abstrak
Kitin merupakan biopolimer yang tersusun atas unit N-asetil-D-Glukosamin. Struktur kitin sangat mirip dengan selulosa yang membedakan pada gugus asetaminda diganti oleh gugus hidroksil pada atom karbonnya. Kitosan sebagai polimer yang tersusun dari 2-amino-2-deoksi- $\beta$-D-glukosa dapat diperoleh dengan cara ekstraksi kitin. Pengubahan molekul kitin menjadi kitosan diperoleh dengan cara mengubah gugus asetamida $(-\mathrm{NHCOCH})$ pada kitin menjadi gugus amina $\left(-\mathrm{NH}_{3}\right)$ pada kitosan. Tujuan penelitian ini adalah mengkarakterisasi kitosan limbah kulit udang meliputi perhitungan rendemen, analisis proksimat dan logam berat. Tahap penelitian terdiri atas proses deproteinasi, demineralisasi, dan deasetilasi. Kitosan yang dihasilkan selanjutnya dianalisis proksimat, kadar logam berat, dan derajat deasetilasi. Hasil analisis karakteristik kitosan menunjukkan rendemen 14\%. Nilai kadar air 12,29\%; kadar abu 0,99\%; total nitrogen 2,20\%; kadar lemak 3,13\%; dan karbohidrat 81,39\%. Viskositas 1713,04 cps; derajat deasetilasi 98,65\%. Kandungan logam berat merkuri 0,00001 $\pm 2,7735$ ppm, kadmium 0,00079 $\pm 3,4641$ ppm, tembaga $0,01105 \pm 1,7320$ ppm, timbal 0,00316 $\pm 2,3094$ dan arsen $0.00098 \pm 1,7320$.
\end{abstract}

Kata kunci : karakterisasi, kitosan, limbah, udang

\section{PROPERTIES OF CHITOSAN FROM GIANT TIGER PRAWN EXOSCELETON}

\begin{abstract}
Chitin is a biopolymer constructed from N-Acetyl-D-Glucosamine units. The structure of chitin closely resembles that of cellulose but is distinguished by the replacement of the hydroxyl group on the carbon atom with an acetyl amine group. Chitosan is a 2-amino-2-deoxy- $\beta$-D-glucose polymer which can be produced by processing chitin. Chitin molecules can be transformed to produce chitosan by changing the Acetamide group $(-\mathrm{NHCOCH})$ for an amine group $\left(-\mathrm{NH}_{3}\right)$. The goals of this research were to determine the characteristics of chitosan from shrimp shelling waste through measuring yield, proximate analysis and heavy metal concentrations. The first stage comprised deproteination, demineralization, and deacetylation processes. The analysis of chitosan characteristics gave a yield of $14 \%$. Proximate analysis yielded the following concentrations: water $12.29 \%$; ash $0.99 \%$; nitrogen $2.20 \%$; fat $3.13 \%$; carbohydrate $81.39 \%$. Viscosity was $1713.04 \mathrm{cps}$ and the deacetylation level was $98.65 \%$. Heavy metal concentrations were Mercury $0.00001 \pm 2.7735 \mathrm{ppm}$, Cadmium 0.00079 \pm 3.4641 ppm, Copper 0.01105 \pm 1.7320 ppm, Lead 0.00316 \pm 2.3094 and Arsenic 0.00098 \pm 1.7320 .
\end{abstract}

Key word : characteristics, chitosan, shrim, waste

\section{PENDAHULUAN}

Teknologi polimer saat ini berkembang dengan pesat seiring dengan semakin beragamnya produk polimer. Eksplorasi terhadap polimer yang pesat mendorong keinginan untuk menemukan jenis polimer yang lebih baik sehingga mudah diperoleh untuk kepentingan aplikasi. Zulfikar dan Ratnadewi (2006) menyatakan bahwa pemanfaatan produk polimer telah berkembang keberbagai aspek kehidupan, sedangkan penghasil polimer difokuskan pada sumberdaya alam yang jauh lebih murah dan mudah didapat. Polimer tersebut merupakan biopolimer, suatu polimer yang mudah diperoleh, dan ramah lingkungan serta mudah terdegradasi.

Kitin merupakan biopolimer organik terbanyak kedua yang ditemukan di alam setelah selulosa, terdapat diberbagai spesies binatang baik darat maupun perairan (Suptijah et al. 1992). Kitosan merupakan senyawa organik turunan dari kitin, senyawa golongan karbohidrat dari biomaterial kitin yang dihasilkan dari limbah laut, khususnya golongan udang, kepiting, rajungan, lobster, ketam, dan kerang-kerangan (Rochima et al. 2007). Kitosan adalah poliglukosamin atau biasa disebut juga dengan B-1,4-2 acetamido-2-dioksi-D-glukosa yang dihasilkan dari kitin dengan proses deasetilasi menggunakan suhu tinggi dan alkali berkonsentrasi tinggi (Dutta et al. 2004; Rochima et al. 2007).

Proses transformasi kitin menjadi kitosan secara umum adalah tahap deasetilasi dengan penggunaan basa kuat misalnya $\mathrm{KOH}$ dan $\mathrm{NaOH}$. Robert (2008) menjelaskan bahwa proses deasetilasi dapat dilakukan dengan konsentrasi basa antara 33$39,5 \%$ suhu $60-80{ }^{\circ} \mathrm{C}$ selama 4-6 hari dan dianggap lebih ramah lingkungan. Hasil karakterisasi kitosan kulit udang diperoleh rendemen 15,21\% (Islama et al. 2011). Kadar air 1,25\% (Mohanasrinivasan et al.

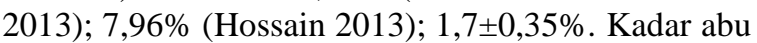
$1,20 \%$ (Islama et al. 2011); 0,91 $\pm 0,1 \%$ (Trung dan Thong 2012); 3,35 $\pm 0,2 \%$ (Walke et al. 2014). Kadar lemak 0,70-4,01 (Naznin 2005). Kadar protein $0,93 \pm 0,1 \%$ (Trung dan Thong 2012). Berat molekul $165.394 \mathrm{kDa}$ (Islama et al. 2011); $110,967 \mathrm{~g} / \mathrm{mol}$ (Patria 2013); 1,05×106 Da (Hossain 2013); 329 $\pm 1,8$ $\mathrm{kDa}$ (Walke et al. 2014). Viskositas 121 $\pm 52 \mathrm{cPs}$ (Trung dan Thong 2012); 191,1 cPs (Patria 2013). Derajat deasetilasi $82,3 \pm 0,5 \%$ (Trung dan Thong 2012); 81,24\% (Hossain 2013); 75\% (Walke et al. 2014). Karbohidrat $74,12 \%$ (Isa et al. 2012). 
Kelarutan $0,9 \pm 0,8 \%$ (Trung dan Thong 2012); $1 \%$ (Walke et al. 2014).

Kitosan umumnya tidak larut dalam air tetapi sedikit larut dalam asam klorida dan asam nitrat serta larut baik dalam asam lemah seperti asam formiat dan asam asetat. Aplikasi kitosan dewasa ini telah banyak digunakan dalam bidang industri baik pangan maupun nonpangan. Menurut Cahyono et al. (2014) kitosan dapat diaplikasikan lebih lanjut dengan memanfaatkan beberapa turunannya seperti oligomer kitosan, karboksimetil kitosan, dan glukosamin. Penelitian ini bertujuan untuk mengetahui mutu kitosan dari limbah cangkang udang windu (Peneaus monodon) sbagai sediaan pangan dan nutraceutika.

\section{METODE}

\section{Bahan dan Alat}

Bahan yang digunakan dalam penelitian ini adalah cangkang udang windu (Panaeus monodon), larutan $\mathrm{NaOH} 3 \mathrm{~N}, \mathrm{HCl} 1 \mathrm{~N}, \mathrm{NaOH} 50 \%$, selenium $0,25 \mathrm{~g}, \mathrm{H}_{2} \mathrm{SO}_{4}$ pekat $3 \mathrm{~mL}, \mathrm{NaOH} 40 \% 20 \mathrm{~mL}$, $\mathrm{H}_{3} \mathrm{BO}_{3} 2 \% 10 \mathrm{~mL}$, indikator bromcresol greenmethyl red, dan benzena. Alat yang digunakan antara lain seperangkat alat produksi kitosan stainless steel, kompor gas, timbangan digital, dan gelas ukur. Alat yang digunakan untuk analisis proksimat antara lain oven listrik, Kjeldahl sistem, tanur listrik, desikator, Sokhlet, alat titrasi, cawan porselin, gegep, gelas piala $200 \mathrm{~mL}$, labu takar, Kjeldahl $50 \mathrm{~mL}$, erlenmeyer $125 \mathrm{~mL}$, pipet tetes, tabung reaksi, labu takar, viscometer, $\mathrm{pH}$ meter, dan alat FTIR.

\section{Tahap Penelitian}

Tahap ekstraksi kitosan limbah cangkang udang dengan menggunakan asam-basa kosentrat meliputi proses deproteinasi (Suptijah et al. 1992), demineralisasi (Naznin 2005), dan deasetilasi (Hossain 2013).

\section{Parameter Uji}

Hasil ekstraksi kitosan dari limbah cangkang udang windu selanjutmnya dianalisis untuk mengetahui kualitasnya meliputi warna, bau dan bentuk (EFSA 2010; GRAS 2012), Rendemen (AOAC 2005), Kadar Air (SNI 2006), Kadar Abu (AOAC 2005), Total Nitrogen (AOAC 2005), Kadar Lemak Disability Soxhletasi (SNI 2006), Viskositas (Sophanodora dan Benjakul 1993), Derajat Deasetilasi (Swann dan Patwardhan 2011), dan Logam Berat (SNI 2013).

\section{HASIL DAN PEMBAHASAN}

\section{Karakteristik Limbah Udang}

Bahan baku yang digunakan pada penelitian ini adalah limbah cangkang udang windu yang diperoleh dari pabrik pembekuan. Hasil karakteristik cangkang udang dapat dilihat pada Tabel 1.

Tabel 1 Hasil karakteristik limbah cangkang udang

\begin{tabular}{lc}
\hline Komposisi Kimia & Persentasi (\%) \\
\hline Kadar air & $12,09 \pm 0,008$ \\
Kadar abu & $24,42 \pm 0,004$ \\
Kadar protein & $20,27 \pm 0,006$ \\
\hline
\end{tabular}

Cangkang udang mengandung beberapa komponen seperti pigmen, mineral, protein, dan kitin. Berdasarkan hasil analisis cangkang udang diperoleh kadar air $(12,09 \pm 0,008 \%)$, kadar abu $(24,42 \pm 0,004 \%)$, dan kadar protein $(20,27 \pm 0,06 \%)$. Hasil penelitian Isa et al. (2012) cangkang udang mengandung protein $(15,05 \%)$ dan kitin $(8,15 \%)$. Ploydee dan Chaiyana (2014) menyatakan limbah kepala udang segar mengandung air $(86,1 \pm 2,2 \%)$, abu $(22,2 \pm 0,6 \%)$, protein kasar $(40,7 \pm 2,7 \%)$, lemak $(13,9 \pm 1,1 \%)$, dan kitin $(23,2 \%)$. Semua komponen dari cangkang udang dapat diisolasi dan diekstraksi dengan menerapkan sistem zero waste sehingga limbah udang tersebut memiliki nilai ekonomis yang tinggi.

\section{Rendemen Kitosan}

Rendemen kitosan hasil penelitian ini adalah 14\%. Berdasarkan hasil penelitian Islama et al. (2011) berkisar 15,21-18\%; Hossain (2013) 15,14\%; Mohanasrinivasan et al. (2013) 17\%. Kitosan dihasilkan melalui proses deasetilasi dengan basa konsentrat. Jumlah rendemen kitosan dipengaruhi oleh konsentrasi reagen, temperatur, waktu reaksi, dan ukuran partikel. Konsentrasi $\mathrm{NaOH}$ tinggi akan meningkatkan jumlah gugus asetil yang terlepas dari kitin sehingga meningkatkan derajat deasetilasi kitosan. Temperatur rendah akan memperlambat laju reaksi. Berdasarkan penelitian Menurut Partia (2013) pengaruh suhu dan waktu pemanasan pada proses deasetilasi kitin akan menurunkan rendemen kitosan. Hal ini dikarenakan suhu yang tinggi akan menyebabkan rantai molekul pada kitosan akan terdepolimerisasi dan mengakibatkan terjadinya penurunan berat molekul dan rendemen kitosan.

\section{Karakteristik Kitosan}

Hasil analisis karakteristik kitosan limbah cangkang udang windu (Panaeus monodon) dapat dilihat pada Tabel 2. 
Tabel 2 Karakteristik kitosan cangkang udang

\begin{tabular}{lccc}
\hline \multirow{2}{*}{ Spesifikasi } & \multicolumn{3}{c}{ (\% Basis kering) } \\
\cline { 2 - 4 } & Hasil Analisis & EFSA 2010 & GRAS 2012 \\
\hline Warna & Putih Kecokelatan & - & White to off white powder \\
Bau & Tidak berbau & - & Netral \\
Bentuk & Serpihan & - & $18-120$ mesh \\
Kadar air (\%) & 12,29 & $\leq 10$ & $\geq 10$ \\
Kadar abu (\%) & 0,99 & $\leq 3$ & $\leq 0.5$ \\
Kadar lemak (\%) & 3,13 & $\leq 1$ & - \\
Total nitrogen (\%) & 2,20 & $\leq 6$ & $0,02 \mathrm{~g} / 100 \mathrm{~g}$ \\
Karbohidrat (\%) & $81,39 *$ & - & - \\
Viskositas (cPs) & $1.713,04$ & - & $25-5.000$ \\
Derajat deasetilasi & 98,65 & $\geq 90$ & $75-95$ \\
\hline Keterangan: & & & \\
\hline
\end{tabular}

Keterangan: *) by difference

\section{Warna dan Bau}

Kitosan yang diperoleh dari penelitian ini berwarna putih kecokelatan dan berbentuk serpihan. Hasil penelitian Suptijah et al. (1992) kitosan berwarna putih kekuningan dan berbentuk serpihan atau bubuk halus. Warna kitosan yang dihasilkan dari penelitian ini disebabkan selama proses demineralisasi dan deproteinasi masih terdapat bahan organik yang belum hilang secara sempurna. Hasil penelitian Ploydee dan Chaiyana (2014) menyatakan bahwa kitosan yang diproduksi dengan cara biologis memiliki warna lebih gelap dibandingkan dengan kitosan yang diproduksi secara kimia. Hal ini diduga masih terdapatnya kandungan protein yang mencapai $0,4 \pm 0,3 \%$ dan kalsium $1,6 \pm 0,6 \%$ selama proses produksi. Berdasarkan GRAS (2012) kitosan komersil berbentuk serbuk, berwarna putih, dan tidak berbau.

\section{Kadar Air}

Kadar air kitosan penelitian ini adalah 12,29\%. Kadar air kitosan hasil penelitian Suptijah et al. (1992) kurang dari 10\%; Isa et al. (2012) 1,40\%; Abdulkarim et al. (2013) 8,70\%; Walke et al. (2014) $1,8 \%$. Kadar air yang tinggi dari hasil penelitian ini diduga diakibatkan terjadinya penyerapan uap air ketika kitosan dalam keadaan terbuka. Hal ini dikarenakan kitosan mengandung gugus amino yang memiliki kemampuan untuk mengikat molekul air. Walke et al. (2014) menyatakan bahwa kitosan merupakan senyawa yang bersifat hidroskopis di alam oleh karena itu, sampel kitosan memiliki kemampuan menyerap air selama peyimpanan. Kadar air kitosan komersil berdasarkan EFSA (2010) yaitu $\leq 10 \%$; GRAS (2012) yaitu $\geq 10 \%$.

\section{Kadar Abu}

Kadar abu kitosan hasil penelitian mencapai $0.99 \%$, yang berarti kandungan mineral yang tersisa sangat sedikit. Hal ini menunjukkan bahwa proses demineralisasi pada pembuatan kitosan telah berjalan dengan baik sehingga tidak banyak mineral tersisa. Kadar abu kitosan hasil penelitian Suptijah et al. (1992) 2,5\%; Islama et al. (2011) 1,20\%; Isa et al. (2012) 5,60\%; Mohanasrinivasan et al. (2013) $2,28 \%$. Kadar abu yang rendah dari kitosan hasil penelitian dipengaruhi oleh konsentrasi asam klorida dan suhu pemanasan. Asam klorida dalam proses demineralisasi berperan melarutkan garam kalsium dengan indikator terbentuknya gas $\mathrm{CO}_{2}$ dan $\mathrm{H}_{2} \mathrm{O}$ dipermukaan larutan. Hasil penelitian Walke et al. (2014) menyatakan bahwa proses demineralisasi akan berjalan dengan baik pada konsentrasi $\mathrm{HCl} 1 \mathrm{~N}$ dengan suhu $110{ }^{\circ} \mathrm{C}$ dan lama pemanasan 30 menit menghasilkan kadar abu 0,48\%. Kandungan abu dari kitosan merupakan parameter yang penting. Kadar abu yang besar dapat mempengaruhi tingkat kelarutan dan dapat menurunkan viskositas. Kadar abu kitosan komersil berdasarkan EFSA (2010) yaitu $\leq 3 \%$; GRAS (2012) yaitu $\leq 1 \%$.

\section{Kadar Lemak}

Hasil pengujian kadar lemak kitosan pada penelitian ini adalah 3,13\%. Hasil penelitian Trung dan Phuong (2012) menyebutkan kadar lemak cangkang udang $11,9 \pm 1,4 \%$. Kadar lemak yang tinggi dari kitosan hasil penelitian dipengaruhi konsentrasi asam pada proses demineralisasi dan konsentrasi basa pada proses deproteinasi. Semakin tinggi konsentrasi larutan diharapkan mampu mendenaturasi protein, lemak, pigmen, dan beberapa bahan organik serta melepaskan mineral pada bahan. Berdasarkan hasil penelitian Naznin (2005) kadar lemak kitosan berkisar 0,70-4,01\%. Hal ini dikarenakan kosentrasi larutan yang tinggi pada proses demineralisasi dan deproteinasi dapat mereduksi protein, lemak, pigmen, dan beberapa bahan organik.

\section{Total Nitrogen}

Kadar nitrogen kitosan dalam penelitian ini 2,20\%. Kadar nitrogen kitosan berdasarkan hasil penelitian Suptijah et al. (1992) $\leq 1 \%$; Trung dan Phuong (2012) 0,93 $\pm 0,1 \%$. Kadar nitrogen yang tinggi dari hasil penelitian diduga diakibatkan proses deproteinasi yang tidak sempurna sehingga menyebabkan rantai asam amino tidak dapat dirombak sehingga denaturasi protein tidak berlangsung dengan baik. Menurut Abdulkarim et al. (2013) kadar protein kitosan yang tinggi dapat dikaitkan dengan waktu perendaman, dan metode yang digunakan selama proses pembuatan kitosan. 
Kadar nitrogen kitosan komersil berdasarkan EFSA (2010) yaitu $\leq 6 \%$; GRAS (2012) yaitu $\leq 0,02$ gram/100 gram.

\section{Karbohidrat}

Hasil perhitungan kadar karbohidrat pada penelitian ini dengan metode by difference menunjukkan bahwa kitosan mangandung karbohidrat $81,39 \%$. Kadar karbohidrat kitosan berdasarkan hasil penelitian Isa et al. (2012) 74.12\%; Kamala et al. (2013) 54,31\%. Metode by difference ini masih digunakan oleh FDA tetapi metode ini dapat menghasilkan nilai yang salah karena ada kemungkinan terjadi akumulasi kesalahan dari metode-metode yang digunakan untuk mengukur komponen lain, dan kemungkinan adanya komponen non karbohidrat yang terukur sebagai karbohidrat dan menyebabkan penyimpangan yang lebih besar.

\section{Viskositas}

Viskositas kitosan yang diperoleh dari penelitian ini adalah 1.713,04 cPs. Viskositas diukur dengan viskometer ubbelohde pada kecepatan $50 \mathrm{rpm}$ menggunakan spindel nomor 2 selama 1 menit. Berdasarkan hasil penelitian Suptijah et al. (1992) nilai viskositas kitosan $600 \mathrm{cPs}$; Trung dan Phuong (2012) 1.214 \pm 52 cPs; Walkes et al. (2014) 602 cPs. Kisaran nilai ini telah masuk standar viskositas kitosan antara 25-5.000 cPs (GRAS 2012). Nilai viskositas yang tinggi dari penelitian ini dipengaruhi oleh distribusi molekul kitosan dalam larutan serta berat molekut dari kitosan, sedangkan berat molekul kitosan berhubungan langsung dengan panjang rantai polimernya. Jika ukuran rantai polimernya menjadi kecil maka laju gerak translasinya menjadi cepat sehingga viskositas menjadi rendah dan sebaliknya. Menurut Avena et al. (2006) semakin tinggi berat molekul dari kitosan maka distribusi molekul kitosan dalam larutan semakin lambat sehingga menghasilkan viskositas yang tinggi, sebaliknya semakin kecil berat molekul kitosan maka distribusi molekul kitosan dalam larutan semakin cepat sehingga menghasilkan kitosan dengan viskositas yang rendah.

\section{Derajat Deasetilasi}

Derajat deasetilasi (DD) merupakan suatu parameter lepasnya gugus asetil dari kitin. Derajat deasetilasi kitosan penelitian ini adalah 98,65\% lebih tinggi dari standar mutu kitosan yang telah ditetapkan (GRAS 2012) yaitu 75-95\%. Berdasarkan hasil penelitian Suptijah et al. (1992) derajat deasetilasi kitosan berkisar 80-90\%; Mohanasrinivasan et al. (2013) 74,82\%; Trung dan Phuong (2012) 82,3 $\pm 05 \%$; Hossain (2013) 81,24\%; Walke et al. (2014) 75-85\%. Derajat deasetilasi merupakan parameter penting yang mempengaruhi sifat kitosan seperti kelarutan, reaktivitas kimia, dan biodegradasi. Spektrum FTIR kitosan dapat dilihat pada Gambar 1

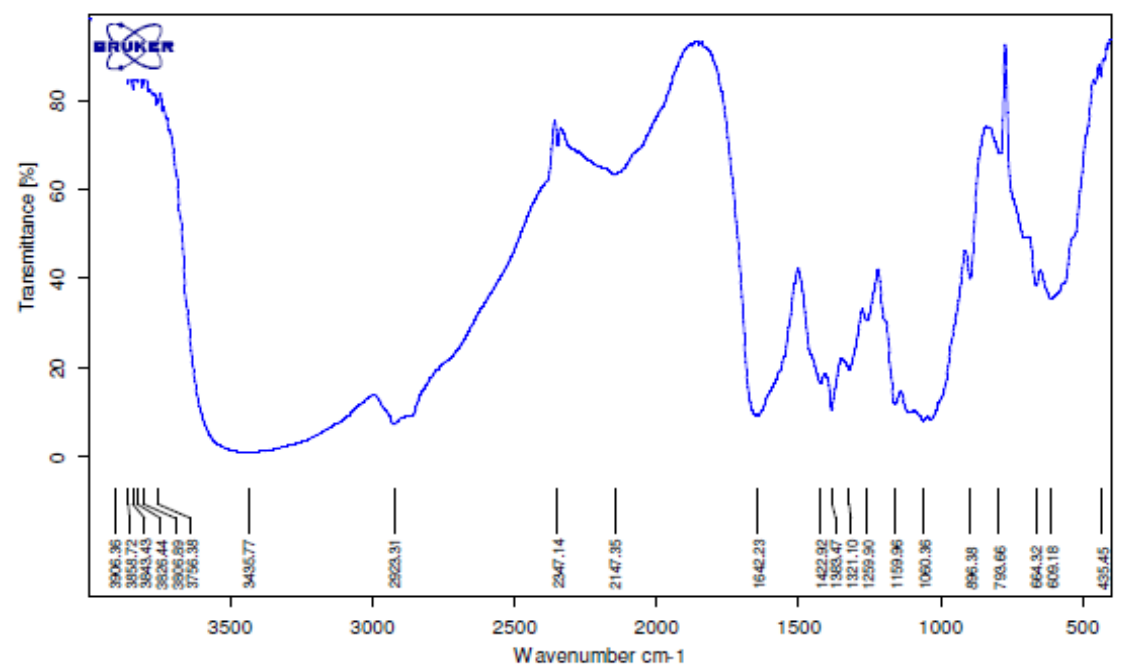

Gambar 1. Spektrum FTIR kitosan cangkang udang

Derajat deasetilasi yang tinggi diduga dipengaruhi oleh proses deasetilasi kitin menjadi kitosan meliputi jumlah larutan alkali yang digunakan, waktu, dan suhu reaksi. Pada penelitian ini menggunakan metode Suptijah et al. (1992) konsentrasi $\mathrm{NaOH} 50 \%$ pada suhu $100{ }^{\circ} \mathrm{C}$ selama 2 jam. Hal ini erat kaitanya dengan laju reaksi dimana konsentrasi $\mathrm{NaOH}$ yang tinggi menghasilkan gugus $\mathrm{OH}^{-}$yang tinggi sehingga gugus $\mathrm{CH}_{3} \mathrm{COO}^{-}$yang terlepas semakin tinggi dan menghasilkan gugus amida yang semakin banyak. Peningkatan suhu pada proses deasetilasi akan meningkatkan kecepatan reaksi dalam deasetilasi molekul kitin menjadi kitosan. Semakin lama waktu proses maka reaksi akan berlangsung semakin lama sehingga molekul $\mathrm{NaOH}$ yang teradisi ke molekul kitin semakin banyak dan menyebabkan gugus asetil yang terlepas semakin banyak.

Shahidi (2005) menyatakan bahwa suhu yang tinggi akan menyebabkan ikatan antar sesama molekul menjadi lemah, viskositas menjadi rendah, dan molekul bergerak lebih cepat sehingga gugus $\mathrm{OH}^{-}$dari larutan $\mathrm{NaOH}$ akan lebih cepat beradisi dengan gugus $\mathrm{NHCOCH}_{3}$ pada kitin dalam 
mengeliminasi gugus asetil. Rokhati (2006) menambahkan bahwa waktu reaksi juga menyebabkan terjadinya degradasi kitosan yang ditandai dengan menurunnya viskositas sehingga lamanya waktu proses tidak begitu berpengaruh terhadap derajat deasetilasi. Sedjati et al. (2007) menyatakan semakin tinggi mutu kitosan berarti semakin tinggi pula tingkat kemurniannya. Kemurnian kitosan dapat dilihat dari kadar air dan kadar abu yang rendah dengan derajat deasetilasi yang tinggi. Semakin tinggi derajat deasetilasinya maka semakin banyak gugus amino pada rantai molekul kitosan sehingga kitosan akan semakin reaktif.

\section{Kadar Logam Berat}

Pengujian kadar logam berat dilakukan untuk mengetahui kandungan logam berat yang terdapat pada kitosan. Hasil pengujian kandungan logam berat dapat dilihat pada Tabel 3 .

Tabel 3 Kandungan logam berat kitosan

\begin{tabular}{lcccc}
\hline Logam & $\begin{array}{c}\text { Hasil Analisis } \\
(\mathbf{p p m})\end{array}$ & $\begin{array}{c}\text { BPOM (2007) } \\
(\mathbf{p p m})\end{array}$ & $\begin{array}{c}\text { EFSA (2010) } \\
(\mathbf{p p m})\end{array}$ & $\begin{array}{c}\text { GRAS (2012) } \\
(\mathbf{p p m})\end{array}$ \\
\hline Merkuri & $0,00001 \pm 2,7735$ & $<5$ & & \\
Kadmium & $0,00079 \pm 3,4641$ & $<5$ & 0,100 & 0,005 \\
Tembaga & $0,01105 \pm 1,7320$ & - & 0,250 & 0,050 \\
Timbal & $0,00316 \pm 2,3094$ & $<5$ & - & - \\
Arsen & $0,00098 \pm 1,7320$ & $<5$ & 0,250 & 0,100 \\
\end{tabular}

\section{Merkuri}

Hasil analisis kandungan logam merkuri kitosan 0,00001 $\pm 2,7735 \mathrm{ppm}$. Nilai ini masih di bawah standar mutu yang ditetapkan oleh BPOM (2007) 5 ppm; EFSA (2010) 0,100 ppm; GRAS (2012) 0,005 ppm. Hasil yang diperoleh menunjukkan bahwa kitosan masih aman untuk dikonsumsi sebagai bahan tambahan makanan. Barrebard et al. (1994) menyatakan bahwa efek keracunan merkuri tergantung dari kepekaan individu dan faktor genetik.

\section{Kadmium}

Hasil pengukuran kandungan kadmium pada kitosan 0,00079 $\pm 3,4641 \mathrm{ppm}$. Nilai ini masih berada di bawah standar yang direkomendasikan BPOM (2007) <5 ppm; EFSA (2010) 0,250 ppm; GRAS (2012) 0,50 ppm. Hasil yang diperoleh menunjukkan bahwa kitosan memiliki kandungan kadmium yang sangat rendah sehingga kitosan dapat dimanfaatkan sebagai bahan tambahan pada makanan. Darmono (1999) menyatakan bahwa kadmium adalah logam non-esenssial yang sering mencemari lingkungan dan mengakibatkan toksik pada hewan dan manusia.

\section{Tembaga}

Hasil pengukuran kandungan tembaga pada kitosan 0,01105 $\pm 1,7320 \mathrm{ppm}$. Nilai yang diperoleh menunjukkan bahwa kitosan memiliki kandungan tembaga yang rendah hal ini dikarenakan tidak adanya aktivitas industri di sekitar perairan yang menghasilkan buangan sehingga kitosan dapat dimanfaatkan sebagai bahan tambahan pada makanan dan nutraseutika. Hendri et al. (2010) menyatakan bahwa logam tembaga merupakan logam esensial bagi hewan air yang bermanfaat dalam pembentukan heamosianin sistem darah dan enzimatik hewan air.

\section{Timbal}

Hasil pengukuran kandungan timbal pada kitosan 0,00316 $\pm 2,3094$ ppm. Nilai ini masih berada di bawah standar yang direkomendasikan BPOM (2007) <5 ppm; EFSA (2010) 0,250 ppm; GRAS (2012) 0,100 ppm. Hasil yang diperoleh menunjukkan bahwa kitosan memiliki kandungan timbal yang sangat rendah sehingga kitosan dapat dimanfaatkan sebagai bahan tambahan pada makanan. Kandungan timbal pada kitosan dapat terdeteksi dengan adanya akumulasi timbal pada pembakaran kendaraan bermotor yang menyebabkan terjadinya peningkatan gas emisi buang yang menggandung timbal.

\section{Arsen}

Hasil pengukuran kandungan As pada kitosan 0,00098 $\pm 1,7320 \mathrm{ppm}$. Nilai ini masih berada di bawah standar yang rekomendasikan BPOM (2007) <5 ppm; EFSA (2010) 0,250 ppm; FDA (2012) 0,100 ppm. Hasil yang diperoleh menunjukkan bahwa kitosan memiliki kandungan As yang cukup rendah sehingga kitosan dapat dimanfaatkan sebagai bahan tambahan pada makanan. Kadar logam arsen yang rendah diduga karena tidak adanya aktivitas industri pertambangan yang membuang limbah ke perairan sekitar tempat pengambilan sampel. Kitong et al. (2012) menyatakan bahwa konsentrasi alami arsen dalam sedimen perairan berkisar antara 1-50 ppm.

\section{SIMPULAN}

Berdasarkan hasil karakteristik kitosan limbah cangkang udang windu dapat disimpulkan bahwa kitosan masuk dalam standar bahan tambahan pangan dan nutraseutika dengan nilai rendemen sebesar 14\%, kadar air 12,29\%; kadar abu 0,99\%; kadar lemak 3,13\%; kadar nitrogen 2,20\%; karbohidrat 81,39\%; viskositas 1.713,04 cPs; dan derajat deasetilasi $98,65 \%$. Untuk kandungan logam berat merkuri $0,00001 \pm 2,7735 \mathrm{ppm}$; kadmium $0,00079 \pm 3,4641$ ppm; tembaga $0,01105 \pm 1,7320$ 
ppm; timbal 0,00316 $\pm 2,3094$ ppm; dan arsen $0,00098 \pm 1,7320 \mathrm{ppm}$.

\section{DAFTAR PUSTAKA}

Abdulkarim, A., Isa, AT., Abdulsalam, S., Muhammad, AJ., dan Ameh AO. 2013. Extraction and characterisation of chitin and chitosan from mussel shell. Civil and Environmental Research. 3(2):108-114.

Avena, B., Olsen, RJ., Olson, CW., Chiou, DA., Yee, E., dan Bechtel, E. 2006. Water vapor permeability of mammalian and fish gelatin films. Journal of Food Sciences. 71(4):202207.

[AOAC] Association of Official Analytical Chemists. 2005. Official Methods of Analysis. 18th ${ }^{\text {ed }}$. Maryland: Association of Official Analytical Chemists Inc.

Cahyono, E., Suptijah, P., dan Wientarsih, I. 2014. Development of a pressurized hydrolysis method for producing glucosamine. Asian Journal of Agriculture and Food Sciences. 2(5):390-396.

Dutta, PK., Dutta, J., dan Tripathi, VS. 2007. Chitin and chitosan, chemistry, properties and applications. Journal of Scientific and Industrial. 63(5):20-23.

[EFSA] European Food Safety Authority. 2010. Scientific opinion on the safety of chitinglucan as a novel food ingredient. European Food Safety Authority. 8(7):1-17.

GRAS. 2012. Chitoclear ${ }^{\circledR}$ shrimp-derived chitosan: food usage conditions for general recognition of safety. Iceland (IL): GRAS

Hadi, AG. 2013. Synthesis of chitosan and its use in metal removal. Chemistry and Materials Research. 3(3):22-26.

Hermanto, MW., dan Chiu, MS. 2007. Robust optimal control of polymorphic transformation in batch crystallization. American Institute of Chemical Engineers Journal. 53(10):2643-2650.

Hobbelen, PHF., Koolhaas, JE., C.A.M. dan vanGestel CMA. 2004. Risk assessment of heavy metal pollution for detritivores in floodplain soils in the Biesbosch, the Netherlands, taking bioavailability into account. Journal Environmental Pollution. 129(11):409-419.

Hossain, MS. 2013. Extraction and characterization of chitosan from shrimp shell and its utilization to increase shelf life of banana. [thesis]. Bangladesh (BL): Bangladesh Agricultural University.

Isa, MT., Ameh, AO., Gabriel, JO., dan Adama, KK. 2012. Extraction and characterization of chitin from nigerian sources. Nigeria. Journal of Practices and Technologyes. 5(4):73-81.

Islama, M., Masum, S., Rahmana, MM., Mollab, AI., Shaikh, AA., dan Roya SK. 2011. Preparation of chitosan from shrimp shell and investigation of its properties. Journal of Basic and Applied Sciences. 11(1):77-80.

Kamala, K., Sivaperumal, P., dan Rajaram, R. 2013. Extraction and characterization of water soluble chitosan from parapeneopsis stylifera shrimp shell waste and its antibacterial activity. International Journal of Scientific and Research Publications. 3(4):1-8.

Leiner, PB. 2006. The physical and chemical properties of gelatin. [internet]. 24 Juli 2014. 1(1): (ES).http:///www.pbgelatin.com.

Spanyol

Mohanasrinivasan, V., Mishra, M., Paliwal, JS., Singh, SK., Selvarajan, E., Suganthi V., dan Devi CS. 2013. Studies on heavy metal removal efficiency and antibacterial activity of chitosan prepared from shrimp shell waste. Journal Biotechnology. 1(3):01-09

Naznin, R. 2005. Extraction of chitin and chitosan from shrim (Metapenaeus monoceros) shell by chemical method. Journal of Biological Sciences. 8(7):1051-1054.

Patria, A. 2013. Production and characterization of chitosan from shrimp shells waste. International Journal of the Bioflux Society. 6(4):339-344.

Ploydee, E., dan Chaiyanan S. 2014. Production of high viscosity chitosan from biologically purified chitin isolated by microbial fermentation and deproteinization. International Journal of Polymer Science. 10(1):01-08.

Robert, GAF. 2008. Thirty years of progress in chitin and chitosan. Bioengineering Research Unit. 10(13):07-15.

Rochima, E., Suhartono, MT., dan Sugiyono DS. 2007. Viscosity and Molecule Weight of Enzymatic Reaction Chitosan by Chitin Deacetylase from (Bacillus papandayan K2914) Isolate. [internet]. Bandung (ID). Hal 118.

januari2014].http://chemistry.unpad.ac.id/iscp roceeding/Pdf/OP/0305310\%20OP081\%2020 Emma\%20Rochima.pdf

Setyawan, AD., Indrowuryanto, W., dan Winarno K. 2004. Pencemaran logam berat $\mathrm{Fe}, \mathrm{Cd}, \mathrm{Cr}$, dan $\mathrm{Pb}$ pada lingkungan mangrove di Propinsi Jawa Tengah. Jurnal Environmental. 4(2):4549.

[SNI] Standar Nasional Indonesia. 2006. Cara uji kimia-Bagian 6: Penentuan kadar logam berat merkuri $(\mathrm{Hg})$ pada produk perikanan. Jakarta (ID): Badan Standarisasi Nasional.

[SNI] Standar Nasional Indonesia. 2006. Cara uji kimia bagian 2: Penentuan kadar air pada produk perikanan. Jakarta (ID): Badan Standardisasi Nasional.

[SNI] Standar Nasional Indonesia. 2013. Metode uji kadar logam berat timbal $(\mathrm{Pb})$ dan kadmium (Cd) dalam produk pertanian dan olahannya 
dengan metode spektrofotometer serapan atom (SSA). Jakarta (ID): Badan Standarisasi Nasional.

Sophanodora, P., Benjakula S. 1993. Convertion an utilization of from prawn shell. Ole BL, Buchanan A, Fardiaz D, editor. Development of food scince and technology in Southest Asia. Proceeding at The $8^{\text {th }}$ Asia Good Conference. Hal:17-21.

Suptijah, P., Salamah, E., Sumaryanto, H., Purwaningsih, S., dan Santoso J. 1992. Pengaruh berbagai isolasi khitin kulit udang terhadap mutunya. Laporan Penelitian. Bogor (ID): Institut Pertanian Bogor.

Swann, GEA., dan Patwardhan, SV.. 2011. Application of Fourier Transform Infrared Spectroscopy (FTIR) for assessing biogenic silica sample purity in geochemical analyses and palaeoenvironmental research. Journal Climate of the Past. 10(7):65-74.
Trung TS., dan Phuong, PTD. 2012. Bioactive compounds from by-products of shrimp processing industry in vietnam. J. of Food and Drug Analysis. 20(1):194-197.

Walke, S., Srivastava, G., Nikalje, M., Doshi, J., Kumar, R., Ravetkar, S., dan Doshi P. 2014. physicochemical and functional characterization of chitosan prepared from shrimp shells and investigation of its antibacterial, antioxidant and tetanus toxoid entrapment efficiency. International Journal of Pharmaceutical Sciences Review and Research. 26(2):215-225.

Zulfikar, dan Ratnadewi, AAI. 2006. Isolasi dan karakterisasi fisikokimia-fungsional kitosan udang air tawar (Macrobrechium sintangense deMan.) Jurnal Teknologi Proses. 5(2):129137. 